\title{
The Effect of Situation of NGO in Yunnan China on Government Purchase of Social Services
}

\author{
Zheng Xiujuan \\ Yunnan university of finance and economics institute of public administration \\ Kunming City, Yunnan Province, China \\ ynkmcat@126.com
}

\begin{abstract}
Yunnan as a province with multi ethnical minority groups and bordering location confronts complex social context and the needs when promoting government purchase of social services. Analyzing the overall features, functions and, attitudes and governance characters of local government, the research considers government purchase of services facing challenges. It is needed for Yunnan province government purchase of social services to foster non-profit civil society organizations, develop government responsibility transferring category and more detailed operational scheme.
\end{abstract}

Keywords - government purchase of service ; social service ; Yunnan; cross border

\section{SUMMARY}

\section{A. NGO Development in Yunnan China and Macroscopic} Background of Government purchase of Service

Government purchase of service is the process that the government provides social services to the community groups who need the service by purchase social services as public products from social service providers. The government purchase of service is a strategy to transfer government functions and develops new government management system. It is more helpful to improve effectiveness of government management over society.

The NGO in this paper means the foundations, civil society groups and non-government non-enterprise organizations. General characters of Yunnan NGO are, number of industry associations is large, lack of non-profit NGO, and for long period, the international NGOs dominate vulnerable community services. The international NGOs (INGO hereinafter) have being carried out activities in Yunnan for over 30 years, and the activities has already covered 16 prefectures of Yunnan. Policy is key factor that restrains local NGO development. Policy reformation in 2014 brought dramatic increase of local NGO, and caused by policy, level of cooperation between INGO and local government is low.

\begin{tabular}{|c|c|c|c|c|}
\hline \multicolumn{5}{|c|}{ Development Profile of Yunnan NGO } \\
\hline Time & Total No. & Type and Number & Increasing Rate & Features \\
\hline 2010 & $12,390^{\mathrm{a}}$ & & & $3000^{\mathrm{b}}$ in the capital city \\
\hline 2012 & $15,603^{\mathrm{a}}$ & $\begin{array}{l}10,845^{\mathrm{b}} \text { industry associations, } 4,710 \mathrm{~b} \text { non-government } \\
\text { non-enterprise organizations, } 38 \text { filed INGO, } 7,342^{\mathrm{b}} \text { filed } \\
\text { urban and rural community NGOs }\end{array}$ & $13.3 \%$ & $\begin{array}{l}\text { Number of NGO meeting provincial annual check standard is } \\
\text { low. Up to } 400^{c} \text { INGOs are carrying out activities in Yunnan, } \\
\text { number of industry association is big, and it is lack of } \\
\text { developed non-profit public service provision NGOs. }\end{array}$ \\
\hline 2014 & & $\begin{array}{l}\text { Newly-registered, } 58 \text { social groups, } 52 \text { non-government } \\
\text { non-enterprise organizations and } 8 \text { foundations }{ }^{\mathrm{d}} \text {. }\end{array}$ & $18 \%$ & $\begin{array}{l}\text { Directly registered NGOs is } 107 \text {, which takes } 90.68 \%{ }^{\mathrm{d}} \text { of the } \\
\text { total newly registered, the NGO development is tremendous. }\end{array}$ \\
\hline
\end{tabular}

a. A notice for "The initiation of the province level of public welfare fund to support NGO to participate in community service project in 2015 " which is issued by Yunnan provincial civil organization administration http://yunnan.mca.gov.cn/article/tzgg/201508/20150800867010.shtml 2015

b. The present situation and Community Party constructive work of Yunnan provincial new social organization http://www.docin.com/p-764146879.htm

c. Shengling etc., The present situation and influences of overseas NGO in Yunnan. Journal of Kunming University of Science and Technology Social Sciences Edition 2013, 06

d. Government purchasing social services helps social organization growing. Xinhua News 2015, 02 
B. Government Purchase Service Development Goal

"Yunnan Province Government purchase of Social Work Services Implementation Methods"(Consultation Paper) (The Method hereinafter) was introduced in May, 2015. There are eight categories of services included in the Yunnan government purchase of social work services. 1) Mobile population support and aid; 2) vulnerable groups care and support; 3)social protection and supportive network instruction for the core empty villages, core empty families and left behind population. 4)daily life care and psychological comfort for the aged people and the handicapped population; 5) psychological support, rehabilitation and social function regaining services for special social groups; 6) social work services in disaster situations; 7)social medical services; 8)social work services for children, women, marriage and family issues. The Method stipulates that the government purchase of services includes purchase social work services posts and purchase social work services programs, and the payment body will be government department at each levels and the state - run institutions that have administrative functions according to the "Civil Servant Management Method". Social group/organization that is included in the administrative establishment management and funded by government finance can also provide social work services through government purchase of service program.

\section{Development Status of Policy and Regulations}

In 2012, Yunnan Civil Affair Department drafted series of supportive documents including, "The Suggestions about Accelerating formation of the Advanced NGO System to Promote Healthy and Organized Development of NGO”, "The Regulations of Promotion Non-profit Work of Yunnan", "The Interim Regulations of Government purchase of Services", "The Service Category (First List) of 2013 Provincial Level Government purchase of NGO Services", "The Management of INGO in Yunnan" to manage NGOs of industry associations, non-profit, scientific and urban and rural community service by direct registration, to support NGO management fund step by step, to establish a supervision system that involves government, society and $\mathrm{NGO}$, and to set up a non-profit projects pool and an authoritative information publicity platform.
Status of Yunnan Government purchase of Service

\begin{tabular}{|c|c|c|c|c|}
\hline Time & Total Input & $\begin{array}{l}\text { Scope of } \\
\text { Services }\end{array}$ & Project Level & $\begin{array}{l}\text { Number of } \\
\text { projects }\end{array}$ \\
\hline 2014 & $\begin{array}{l}\text { RMB } \\
28,441,300^{\mathrm{a}}\end{array}$ & $\begin{array}{l}\text { Social work } \\
\text { service, } \\
\text { retirement } \\
\text { service, NGO } \\
\text { service, etc. }\end{array}$ & $\begin{array}{l}\text { Provincial level } \\
\text { terms and } \\
\text { government } \\
\text { projectterms }\end{array}$ & \\
\hline \multirow[t]{2}{*}{2015} & \multirow[t]{2}{*}{$121,835,500^{\mathrm{b}}$} & $\begin{array}{l}\text { HIV/AIDS } \\
\text { prevention and } \\
\text { control }\end{array}$ & $\begin{array}{l}\text { Provincial and } \\
\text { nationallevel } \\
\text { terms }\end{array}$ & $106+42$ \\
\hline & & $\begin{array}{l}\text { Teenager social } \\
\text { service, etc. }\end{array}$ & $\begin{array}{l}\text { Provincial level } \\
\text { terms }\end{array}$ & 17 \\
\hline
\end{tabular}

a. A notice for "The initiation of the province level of public welfare fund to support NGO to participate in community service project in 2015 " which is issued by Yunnan provincial civil organization administration http://yunnan.mca.gov.cn/article/tzgg/201508/20150800867010.shtml 2015 b Yunnan provincial governmental department will spend 1.2 billion to purchase social services in year 2015. Yunna Information News

\section{Situation of Social Service Personnel}

By 2013, there are up to 210,000 people involving in social work in Yunnan province, amongst which 13,000 are social work professionals, while only over 1000 have an occupational certificate. There is a great gap between both the number and capacity of social work personnel and the community need. Both low professional level and high part-time level directly effect on forming and development of NGO.

\section{Development Features of NGO Development IN YUNNAN PROVINCE}

\section{A. Human Resource Insufficiency}

1) Short of Full-time Staff

According to statistics in 2012, there were 100,000 full 
time/part-time staff members in 12,390 NGOs in Yunnan, amongst which 36,000 were full time staff members, that is 3 full time staff members in each NGO on average. Excluding non-government non-profit organizations, huge portion of NGOs are lack of full time employers. The information provided by Yunnan Provincial Political Consultative Committee, at present, in the 22 youth and teenager affairs social work service centers that fostered by Yunnan government, there are only 33 full time social workers and more than 190 part time staff members.

\section{2) Lack of Management Personnel}

In most situations, the person in charge of a NGO also holds the post of the leader of the reporting government department of that NGO or is the leader person in that professional field. This leads the management of NGOs involves in heavy administrative influence and very vague division of duties caused by dual positions. Some NGO are not able to neither continue social work activities nor receive annual inspection and remains an empty rack due to change and/or leave of the founder.

\section{3) Lack of Professional Personnel}

Because of limitation of NGO development and brain drain from local, NGOs in Yunnan could not absorb high level intellectuals to involve in NGO work. Currently, in the 22 youth and teenager affairs social work service centers that fostered by Yunnan government, there are less than 20 social workers have social work qualification.

\section{4) Frequent Personnel Flow}

The personnel in NGO are flowing around heavily because long time developing isolate, unsustainability and instability of their work, and low reward for the staff. NGO personnel are part -time staff predominated without support from government, and full time staff would leave an NGO as there is not much career development. Kunming Black Headed Gull Youth and Teenager Affairs Service Center recruited 17 staff members by two times of recruitment each in 2013 and 2014, and 10 of them left so far.

\section{B. Funding Challenge Caused by Related Support}

Most NGOs maintain operation and carry out activities solely depending on charge of membership, and a few NGOs are able to obtain irregular funding support from government. NGOs do not form an effective funding chain yet. They over depend on government contribution or charge of membership. And there are only a few NGOs obtain funding by using government function transferring. A good funding resource combination for a NGO should have one half each from government distribution and from society resource. The activities NGOs carry out become intermittent and low organizational self-governance without stable funding chain. This dramatically contributes NGOs' function to be carried out and stability of personnel.

\section{Loose Internal Management Systems because of Immature Organizational Development}

Most NGOs could not set up established management systems, and have no power to bind or support its membership. The management team is usually lack of stability and nor professional enough. NGO management either applies a government administrative model or in a loose situation.

\section{Multi Head Management Leads NGO Lacks of Self Governance}

In the past, NGOs all were under supervision of more than two government departments, one is civil affair department for registration management, and the other is a functional government department of professional supervision. The reality is that the civil affair department only plays the role in objective assessment of registration fund of $\mathrm{NGO}$, number of staff members, office venue, etc. and annual inspection. While the functional department does not provide support, instead, becomes obstacle when NGOs carry out activities, for instance, the numerous and jumbled approval procedures, low efficiency office work style do not assist coordination of social resource. Secondly, confusion of responsibilities of the government management bodies about NGO sustains forming of NGO self-motivation.

\section{E. Strict Requirement for NGO Registration Makes Obtaining Legal Legislation and Development Assistance Difficult}

Revents lots of NGO helping local development from obtaining legal legislation. By 2012, there are 7342 urban and rural NGOs put their files because they could not succeed 
registration at the civil affair department, 38 put their files abroad. This indicates that there are lots of NGOs in Yunnan could not acquire the eligibility for government purchase of service. Application requirement such as for office venue, funding and organization structure standard $\mathrm{p}$

\section{F. Lacking Greatly of Native Non-profit NGO in Yunnan}

For the moment, NGO eligible to government purchase of service is dominated in provincial city with limited scale-up, and in the less developed places, there is rarely any local non-profit NGO exists. The total registered NGO in Yunnan in 2010 is 12,390, with 4 prefectures and/or cities have more than $1000 \mathrm{NGO}$ registered at government department, while there were 3000 in Kunming, the capital city. By the end of 2012, there were 10,845 social groups including industry associations, the industry association covers most, and the number of NGOs eligible for government purchase of service was very small. For example, in three border counties of Wenshan prefecture, types of NGOs inclines in minority culture and breeding and farming associations, the social service non-profit NGO falls short of.

\section{G. INGOs in Dominated Position among NGOs in Yunnan}

After promulgation of "Yunnan Interim Provisions to Regulate the International NGOs in Yunnan" (the Interim Provisions hereinafter)in 2012, there were only 38 INGOs out of more than 200 INGs in Yunnan province get registered. However, there were actually more than 270 INGOs of over 20 other countries carried out activities in Yunnan in 2012. At the moment there are 140 INGOs set their office and conducting activities in Yunnan. In 2011, the projects of INGO filed at Yunnan Provincial Foreign Affairs Office reaches 288, 128 was in 2012 and 16 was in 2013. Active INGOs in Yunnan are mostly from developed counties or regions, their non-profit service projects cover all over prefectures, cities and counties of Yunnan in the areas of poverty support, disaster relief, primary education, drinking water for man and livestock, ecological protection, HIV/STI prevention and control, drug control, health education, disabilities rehabilitation, Child welfare, community development, aid and support to orphans by HIV and/or poverty and woman, etc.
In 2013, both number of INGOs and their cooperation projects got a dramatic decrease. Reasons analyzing from institutional and practical aspects, "the Interim Provisions" comes first, it restricts organizational legality from administrative law enforcement entity. Secondly, in the way of dual filing and requirement of interfere of government management department makes INGO activities effectiveness becomes low, even, could not carry out activities. Thirdly, obligation of cooperation partners in the local has to be a legal NGO in China makes continuation of INGO project activities difficult. Withdrawal of international funding and INGOs from Yunnan affect forming and developing of puerile local non-profit NGOs.

\section{H. Long time of Administrative Interfere and top-down formation mechanism results in the Number of NGO Considerable, but Low Outcomes}

From interviews, there are number of NGOs in many places of Yunnan formed upon local government. The administration layers are complicated, especially for the associations, which there is nearly no any activity or social function. For the community based NGO (CBO hereinafter), suffered by less development of society and local government management attitudes, the development of CBO could not get moved forward. Therefore, it is invalid to decide development status by the number of NGO in Yunnan.

\section{Drag force AnALysis of YunNAN GOVERnMENT PURCHASE OF SOCIAL SERVICE}

\section{A. Serious Shortage of Social Work Professionals Affects} Forming of $\mathrm{NGO}$

From the direction of employment of social work graduates, only a few involve in social work field for low level of payment and limited career development space. There is no universal standard for social worker's salary. Apart from a few graduates hired by the civil affairs departments in the way of civil servant, the welfare treatment of other posts like social workers in welfare house and the street running office is just more or less close to the general health care workers. For the problem of personnel control, their residential and housing are very difficult to work out. By 2013, there is only 
$10 \%$ of the employed hold a social worker occupation qualification certificate. By the $15 \%$ rate of passing the examination, and $20 \%$ of those passed joined social service work, the total number of social work professionals in 2015 could only increase about 2000. Meanwhile, every NGO is able to carry out government purchase of service project at least has to have 3 qualified social workers. Shortage of social work professionals could not foster adequate non-profit NGOs.

\section{B. Small Number of NGOs Could not Meet High Quality}

Requirement by the Government purchase of Service

Currently, for its small number, the public service NGOs in Yunnan are not able to reach Requirement by the Government purchase of Service. In most places, it presents a general feature that development of the government operated NGOs are better than community based NGOs. Limited number of the government operated NGOs can't form open competition, and it easily results in an in-system recycle. An independent and equal relation can't be established between the purchase entity and the service provision entity. Government purchase of service will possibly transfer into government authorization. This will lead to adverse consequence of low quality but high price of government purchase of service, vague interest boundary between purchase body and service providers, and collusion between businesses and government officials. If there is no open and fair competition, in order to form an effective and/or adequate level of competition pattern, certain number of NGOs and their active involvement in competition process are the basic conditions necessary.

\section{Limited Space for government Function Transferring}

Existing for Time will lead to Prolong of Development Cycle of Government purchase of Service

Since arising of demand for government function reforming, the big gap for transferring is still in office stationary purchase, transportation service and infrastructure construction, education, medical and health. Most of public social services surrounding eight areas listed earlier remain blank for functions to be transferred. The functions still are included in the civil administration system. The government functions are not transferred and transited, government officials are not even aware that social services could be taken over by NGO, and cannot imagine to hand over services like supporting the aged people, aid for the handicapped, moving around the population to NGO. It reflects in government work report and plans that these kind of work are still carried out by communist youth league commissions and civil administration departments. There is only one provincial NGO directory introduced in Yunnan by now. Therefore, government purchase of service of Yunnan has long way to go.

\section{Enormous Exploration is still needed as an Integrated System is not Developed Yet}

Three level categories of provincial, city and county have been introduced in the provinces/regions where the government purchase of social services promoted early. The first is the category that the government needs to transfer, the second is the government intends to purchase from NGO, including content, title, item and price rate; the third is major entity that will take over public services. However, both the "The Interim Regulations of Government above County Level Purchase Services From NGO" and "Yunnan Provincial Government Implementation Measures of Purchase Social Work Service, May, 2014" developed by Yunnan Government are just regulative documents that are not operational nor practical, instead of forming a complete category.

Yunnan province started $77 \mathrm{HIV} / \mathrm{AIDS}$ prevention and control government purchase of services projects in 2014. In 2015, 17 NGO involved projects Supported by Yunnan Welfare Lottery Public Non-profit Fund. A complete project cycle of government purchase of services is not completed yet, and it still needs lots of exploration. In other provinces, through practice of government purchase of service, challenges are already identified for pricing of social service, monitoring mechanism, granting and performance assessment, while in Yunnan, policies and regulations about government purchase of service developed do not raise any solution for the issues mentioned above. 
IV. CONCLUSION: RECOMMENDATIONS FOR THE

DEVELOPMENT OF YUNNAN PROVINCE GOVERNMENT PURCHASE OF SOCIAL SERVICES

\section{A. Continue to implement NGO direct registration system}

To establish new system and mechanism to manage and guide NGO, encourage growth of NGOs that are suitable for local needs. In management model and system, increase government departments' understanding of NGO, and to give sufficient space for NGO development.

B. To Develop Standard Operational Evaluation Procedures for the Government purchase of Social Services.

On the foundation of current purchase project being implemented, to improve the policy system in speed by learning experience from other places. To develop pricing principle system and super vision for mulation of social services, to set up specialized agencies of management and performance evaluation. Operational regulations concerns about NGO operation, sustainability and realization of social functions. Practice in the matured developed places reflects that the biggest challenge is related to disbursement of funds service quality evaluation. Therefore, Yunnan province government purchase of social services should establishes specific and feasible systems in these two aspects as priority.

\section{To Strengthen Input and NGO Professionals Development}

In view of the lack of NGO professionals and features such as mobility, the government can adopt corresponding measures to support the construction of talent team to fit the NGO needs of various administrative areas of social services and economic development. At present, due to little recognition for the profession and treatment, there is a huge drop-off of social workers, which plays very negative effect on development of NGO and its social function. Yunnan Province is limited to local education level; economy development status and the disadvantage position in, the local NGOs are lack of capacity to absorb talented professionals. Only if the government can put efforts in employment treatment and posts setting, can high-quality NGO teams be established and a supportive environment for NGO development is formed.
D. The Government Needs to Effectively Guide the Existing NGO, and Provide Focused Support and Authority Transferring Space to the Typical NGOs in its Administrative Areas of Governments at all Levels.

For over long time, government does not have scientific attitude and guide mechanism in NGO management. It leads to a high degree of homogeneity of the NGO, cumbersome hierarchical structure. It should encourage the social service function of NGO establishment and development to fill blank areas of social services as soon as possible. The government should play the role of macroeconomic regulation and control, on the basis of scientific research of NGO system planning, take social functions as the evaluation standard, to reduce the hierarchical system of NGO, provide favorable conditions to those NGOs have social service function. For its geographical location, multi ethnical minority groups and economic development condition, Yunnan province has a portion of NGO with local characteristics, such as ethnical culture and the ethnic relations adjustment function of NGO, and another portion of NGOs providing services for the special social groups of people. They should have more government support and the power transferring space. Through government resources, provide good projects and good platform to NGOs, and to increase possibilities of the government purchase of services for the NGOs.

E. All Levels of Government to List Services for Purchase that are Suitable for Social Needs in the of the Region Instead of Blindly Following the Provincial Project.

Yunnan province is very culturally and economically diversified and unbalance in development with its ethnical minority group sand cross-border location. Social service needs and satisfaction are different greatly. In general, basic needs for social services should be a bottom-up process, and social services will result in better social recognition and resource utilization if the services are set from angle of community needs services. The Yunnan provincial government purchase of social services takes the capital city as the base to start the pilot, for example, 77 items of the HIV/AIDS prevention and control project that is under implementation also includes subordinate regional levels. But this cannot be the regular condition; governments at all levels need list out 
local social service directory of service for the most in need. Through the process of social surveys and needs assessments, to help and support development of NGOs that fit the local needs.

\section{F. Assess and Regulate the Existing Public Non-profit NGO.}

NGO resources in Yunnan Province should not be ignored and abandoned. NGOs existing but not registered yet that have undertaken related social services, with help and support to improve its social functions after assessing; can be included in the mainstream of government purchase of services.

\section{ACKNOWLEDGEMENT}

Thanks for the support from government departments of Yunnan Wengshan prefecture, Dali prefecture, HeKou county and MoHang county and the interview with governmental officials to help to obtain information and data for the completion of this research.

\section{REFERENCES}

[1] The present situation and Community Party constructive work of Yunnan provincial new social organization http://www.docin.com/p-764146879.html

[2] The 4th development documentation Solicit opinions of Yunnan push on social organization

http://roll.sohu.com/20130723/n382333167.shtml

[3] An outlook of Yunnan social organization innovation "box combination"2013, 08

[4] A notice for "The initiation of the province level of public welfare fund to support NGO to participate in community service project in 2015" which is issued by Yunnan provincial civil organization administration http://yunnan.mca.gov.cn/article/tzgg/201508/2015080086701

0.shtml 2015
[5] Government purchasing social services helps social organization growing. Xinhua News2015, 02

[6] Yunnan provincial governmental department will spend 1.2 billion to purchase social services in year 2015. Yunnan Information News2015-07-27

[7] Yunnan social workers is about 210,000 and the demand gaps still big. Yunnan news2014-03-24 06:36:45

[8] Yunnan: Social worker line unchanged for 20 years. It's time to change. Chinese Youth Newspaper March 11th,2015

[9] Hou JiangHong"The present situation and standard Specification countermeasures of overseas NGO in Yunnan"minority area.2012, 26,

[10] Sheng ling etc, "The present situation and influences of overseas NGO in Yunnan" Journal of Kunming University of Science and Technology Social Sciences Edition2013， 6

[11]Interim provisions of Yunnan province regulate overseas NGO activities http://wenku.baidu.com/view/523878ebb8f67c1cfad6b8d2.htm 12010,02

[12] Chen Ying,"Study on the legal system for the entry of Yunnan overseas NGO”, Master Thesis 2012

[13] Xu Guangjian,"The Key Difficulty and Path of Government to promote the Purchase of Public Service"Frontline, 2014(5)

[14] GaoShang: Discussion on government procurement of services and social organization development. Contemporary Economy \& Management, 2015,09 